\title{
Erratum to: Elucidation of the Nature of Structural Heterogeneity During Alkali Leaching of Non-activated and Mechanically Activated Boehmite $(\gamma-\mathrm{AlOOH})$
}

RAKESH KUMAR and THOMAS C. ALEX

DOI: $10.1007 / \mathrm{s} 11663-015-0372-4$

(C) The Minerals, Metals \& Materials Society and ASM International 2015

Erratum to: METALLURGICAL AND

MATERIALS TRANSACTIONS B

DOI: 10.1007/s11663-015-0343-9

THE correct references [26] and [27] are as follows:

26. Rakesh Kumar, T.C. Alex, M.K. Jha, Z.H. Khan, S.P. Mahapatra, and C.R. Mishra: in Light Metals 2004, A.T. Tabereaux, ed., The Minerals, Metals \& Materials Society, Warrendale, PA, 2004, pp. 31-34.
27. Rakesh Kumar, T.C. Alex, Z.H. Khan, S.P. Mahapatra, and S.P. Mehrotra: in Light Metals 2005, H. Kvande, ed., The Minerals, Metals \& Materials Society, Warrendale, PA, 2005, pp. 77-79.

RAKESH KUMAR, Chief Scientist and Head of Division, THOMAS C. ALEX, Principal Scientist, are with Metal Extraction and Forming Division, National Metallurgical Laboratory, Jamshedpur 831 007, India. Contact e-mail: rakesh.nmlindia@gmail.com

The online version of the original article can be found under doi: 10.1007/s11663-015-0343-9.

Article published online May 20, 2015. 